\title{
CORRELATION OF C-REACTIVE PROTEIN AND COPD SEVERITY
}

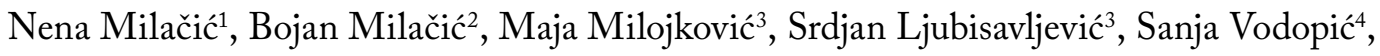 \\ Mirha Hasanbegovićs and Marija Đurovic ${ }^{6}$
}

${ }^{1}$ Clinical Department of Pulmonology, ${ }^{2}$ Clinical Department of Thoracic Surgery, Clinical Centre of Montenegro, Podgorica, Montenegro; ${ }^{3}$ University Department for Pathophysiology, School of Medicine, University of Niš, Niš, Serbia; ${ }^{4}$ Clinical Department of Neurology, Clinical Centre of Montenegro; ${ }^{5}$ Clinical Department of Internal Medicine, Pljevlja General Hospital, Pljevlja; ${ }^{6} \mathrm{Clinical}$ Department of Internal Medicine, Clinical Centre of Montenegro, Podgorica, Montenegro

\begin{abstract}
SUMMARY - Chronic obstructive pulmonary disease (COPD) is a progressive pulmonary disease characterized by systemic inflammation. The aim of this study was to correlate the parameters of systemic inflammation, $\mathrm{C}$-reactive protein $(\mathrm{CPR})$ and total leukocyte count, with clinical indicators of the disease. Our study included 157 COPD patients, both outpatients and those hospitalized at the Knez Selo Department of Pulmonology of the Niš Clinical Centre during a six-month period, while in the phase of disease exacerbation. The symptoms of COPD in each patient were estimated by the COPD Assessment Test (CAT) and modified Medical Research Council (mMRC) dyspnea scale. The parameters of pulmonary function (FEV1 and FVC), acid-base status, body mass index, history of exacerbation and comorbidities were also evaluated. The level of CRP, but not leukocytes, showed significant correlation with the severity of clinical presentation according to GOLD classification. The higher the CRP concentration, the higher was the disease severity determined according to GOLD classification $(p<0.001)$. There was no statistically significant difference in CRP level and leukocyte count according to comorbidities $(p=0.29)$. The level of CRP was higher in patients with a high CAT score and mMRC scale $(\mathrm{p}<0.001)$. The same trend was observed for leukocyte count when compared with CAT results, but not when correlated to mMRC scale. The level of CRP during COPD exacerbation can be an independent predictor of the disease severity and paraclinical findings.

Key words: Pulmonary disease; Chronic obstructive pulmonary disease - diagnosis; Chronic obstructive pulmonary disease - classification; C-reactive protein; Respiratory function tests; Severity of illness index; Surveys and questionnaires
\end{abstract}

\section{Introduction}

Chronic obstructive pulmonary disease (COPD) is a common and treatable disease characterized by persistent airflow limitation that is usually progressive and associated with an enhanced chronic inflammato-

Correspondence to: Nena Milačic, $M D$, Department of Pulmonology, Clinical Centre of Montenegro, Ljubljanska bb, Podgorica, Montenegro

E-mail: nenamilacic75@gmail.com

Received July 6, 2015, accepted November 24, 2015 ry response in the airways and the lung to noxious particles or gases. Exacerbations and comorbidities contribute to the overall severity in individual patients ${ }^{1,2}$. COPD is currently the fourth leading cause of death and a considerable economic and social burden worldwide, especially in underdeveloped countries ${ }^{3-6}$.

Diagnostic and therapeutic parameters used to evaluate COPD are based on assessment of symptoms, severity of airflow limitation, history of exacerbations, and comorbidities ${ }^{2}$. The COPD Assessment Test (CAT) is a short, easy-to-complete health status 
tool that has been developed to help patients and their clinicians assess and quantify the symptoms and impacts of $\mathrm{COPD}^{7,8}$. On the other hand, a weak breath is the most common symptom reported by long-term COPD patients ${ }^{9}$, and it significantly reduces the quality of life $\mathrm{e}^{10,11}$. Therefore, it is necessary to estimate patients' airflow and thus modified Medical Research Council (mMRC) dyspnea scale is used ${ }^{12}$. It is simple to use with a predictive value and it correlates with clinical and functional pulmonary parameters ${ }^{13-15}$.

Numerous studies have confirmed that acute exacerbations of COPD imply increased levels of C-reactive protein (CRP), as well as modification of other inflammatory parameters ${ }^{16-18}$.

The aim of this study was to correlate the inflammation parameters of CRP and leukocyte count with clinical indicators of COPD (disease symptoms assessed by CAT and mMRC dyspnea scale, history of exacerbation and comorbidities, and blood gas analysis results). To our knowledge, no similar study has been conducted in Serbia and Montenegro to date.

\section{Patients and Methods}

This prospective study was conducted in the Niš Clinical Centre and was approved by the institution
Ethics Committee. Before taking part in the research, a written consent was obtained from each patient. The research included 157 patients ( 115 men and 45 women) suffering from COPD, both outpatients and those hospitalized at the Knez Selo Department fo Pulmonology of the Niš Clinical Centre during a sixmonth period (from November to May 2013). Patients diagnosed with bronchial asthma, pneumonia and decompensated cardiomyopathy were excluded, as well as those who had suffered myocardial infarction in the last 6 weeks. Patients included in the study were experiencing an exacerbation of the disease.

The diagnosis of COPD was made based on GOLD guidelines ${ }^{2}$. Inclusion criteria were postbronchodilation test ratio of the forced expiratory volume in the first second (FEV1) and the forced vital capacity (FVC) below 70\%. The questionnaire used for estimation of COPD-CAT and mMRC dyspnea scale, as well as spirometric parameters were obtained during first outpatient or hospital treatment. The questionnaires were translated and back translated into Montenegrin language. All patients filled them in by themselves. Doctors did assist patients but did not suggest any answer.

Blood analysis was done in all patients. Spirometric parameters, FEV1 and FVC, were obtained using

Table 1. General and demographic characteristics of patients

\begin{tabular}{|l|l|c|c|}
\hline Variable & & $\mathrm{N}$ & $\%$ \\
\hline Gender & Male/Female & $115 / 42$ & $73.2 / 26.8$ \\
\hline Smoking habit & Non smokers & 25 & 15,9 \\
\hline & Smokers & 68 & 43,3 \\
\hline & Ex smokers & 64 & 40,8 \\
\hline Exacerbations & Rare/Frequent & $42 / 115$ & $26.8 / 73.2$ \\
\hline Age & & $67.76 \pm 9.39$ & $68.00(41.00-89.00)$ \\
\hline BMI & & $26.61 \pm 6.28$ & $25.88(15.59-57.48)$ \\
\hline FEV1 & & $1.26 \pm 0.54$ & $1.13(0.33-2.87)$ \\
\hline FEV1\% & & $47.08 \pm 14.93$ & $45.50(16.60-79.90)$ \\
\hline FVC & & $2.34 \pm 0.88$ & $2.25(0.68-5.03)$ \\
\hline FVC\% & & $69.38 \pm 17.80$ & $67.50(28.90-105.80)$ \\
\hline CRP & & $25.09 \pm 29.72$ & $11.60(1.20-110.00)$ \\
\hline Leukocyte count & & $9.06 \pm 3.08$ & $8.30(3.50-18.60)$ \\
\hline
\end{tabular}

$\mathrm{BMI}$ = body mass index; FEV1 = forced expiratory volume in 1 second; FVC = forced vital capacity; $\mathrm{FEV} 1 \%$ = FEV1/FVC ratio; $\mathrm{FVC} \%$ = percent predicted forced vital capacity; $\mathrm{CRP}=\mathrm{C}$-reactive protein 
Table 2. Patient characteristics in relation to GOLD classification

\begin{tabular}{|l|c|c|c|c|}
\hline & GOLD 2 & GOLD 3 & GOLD 4 & \multirow{2}{*}{$\mathrm{p}$} \\
\cline { 2 - 4 } & $\mathrm{n}=60$ & $\mathrm{n}=79$ & $\mathrm{n}=18$ & \\
\hline Age $(\mathrm{yrs})$ & $67.67 \pm 9.49$ & $68.29 \pm 9.85$ & $65.78 \pm 6.84$ & 0.592 \\
\hline Gender $(\mathrm{M} / \mathrm{F})$ & $43 / 17$ & $58 / 21$ & $23.66+/-5.33$ & 0.875 \\
\hline BMI & $28.18 \pm 7.17$ & $26.08 \pm 5.43$ & $23.66 \pm 5.33$ & 0.015 \\
\hline Exacerbation & $1.55 \pm 1.57$ & $5.44 \pm 2.62$ & $9.83 \pm 1.69$ & $<0.001$ \\
\hline FEV1 & $1.75 \pm 0.52$ & $1.02 \pm 0.25$ & $0.67 \pm 0.12$ & $<0.001^{\mathrm{a}}$ \\
\hline CAT & $17.98 \pm 6.37$ & $27.94 \pm 6.34$ & $34.89 \pm 2.76$ & $<0.001^{\mathrm{b}}$ \\
\hline mMRC & $1.33 \pm 0.71$ & $2.52 \pm 0.90$ & $3.67 \pm 0.48$ & $<0.001^{\mathrm{b}}$ \\
\hline CRP & $9.34 \pm 14.14$ & $26.74 \pm 32.66$ & $38.79 \pm 27.78$ & $0.006^{\mathrm{b}}$ \\
\hline Leukocyte count & $8.99 \pm 3.64$ & $8.67 \pm 2.76$ & $10.38 \pm 3.18$ & $0.264^{\mathrm{b}}$ \\
\hline
\end{tabular}

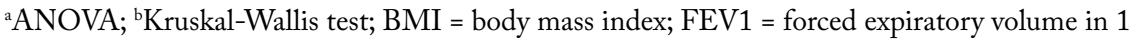
second CAT $=$ COPD Assessment Test $; \mathrm{mMRC}=$ modified Medical Research Council scale; CRP

$=\mathrm{C}$-reactive protein

the Erich Jaeger Masterlab (Germany) spirometric apparatus. Electrocardiography, chest radiography, information on the disease duration, comorbidities and exacerbations in previous year were obtained from the patients.

\section{Statistics}

Demographic variables (i.e. gender, age and smoking status) as well as clinical determinants were summarized in order to characterize the study population. Statistical analysis included descriptive statistics, Kolmogorov-Smirnov test, t-test, ANOVA, Kruskal Wallis test and regression analysis. The value of $\mathrm{p}$ less than 0.05 was considered statistically significant. The SPSS version 16.0 statistical program was used on data analysis.

\section{Results}

Table 1 summarizes demographic and clinical characteristics of study patients. The study was performed on 157 patients, mainly male $(n=115)$ and smokers $(n=68)$, mean age 67.76 \pm 9.39 . Patients with a more severe form of COPD, i.e. those with a higher class of disease severity according to GOLD, had much more frequent exacerbations, higher CAT score and higher mMRC dyspnea score $(\mathrm{p}<0.001)$. CRP showed significant correlation with the severity of clinical presentation. The higher the CRP level, the higher was the class of disease severity accord- ing to GOLD $(\mathrm{p}=0.005)$. These data are presented in Table 2.

Post hoc analysis determined that patients without comorbidities had a statistically significantly lower body mass index (BMI) in comparison to both patients with two or less comorbidities and patients with three or more comorbidities ( $\mathrm{p}=0.01$ both). There was no statistically significant difference in CRP level and leukocyte count according to comorbidities. The values of FEV1 (L), FVC (L) and FVC (\%) decreased statistically significantly with the increase of comorbidities $(\mathrm{p}=0.028, \mathrm{p}=0.002$ and $\mathrm{p}=0.005$, respectively). These results are shown in Table 3.

Patients with a high CAT score had statistically more frequent exacerbations $(p<0.001)$. BMI was statistically significantly lower in patients with a high CAT score $(\mathrm{p}=0.02)$. CRP value was statistically significantly higher in patients with a high CAT score $(\mathrm{p}<0.001)$. Leukocyte count was statistically significantly higher in patients with a high CAT score ( $\mathrm{p}=0.002)$. These results are summarized in Table 4.

Patients with a high CAT score had significantly lower values of FEV1 (L), FEV1\%, FVC (L) and FVC\% ( $<<0.001$ all), and lower values of partial oxygen pressure $(\mathrm{pO} 2 ; \mathrm{p}=0.016)$, bicarbonate $(\mathrm{HCO} 3$; $\mathrm{p}=0.025)$ and oxygen saturation $(\mathrm{sO} 2 ; \mathrm{p}=0.023)$. The values of partial carbon dioxide pressure $(\mathrm{pCO} 2)$ in arterial blood were statistically significantly higher in patients with a high CAT score $(\mathrm{p}=0.014)$ (Table 5). 
Table 3. Demographic and clinical characteristics of patients in relation to comorbidities

\begin{tabular}{|c|c|c|c|c|}
\hline & \multicolumn{3}{|c|}{ Comorbidities } & \multirow{3}{*}{$\mathrm{p}$} \\
\hline & $\begin{array}{c}\text { Without } \\
\text { comorbidities }\end{array}$ & $\leq 2$ & 3 or more & \\
\hline & $\mathrm{n}=32$ & $\mathrm{n}=104$ & $\mathrm{n}=21$ & \\
\hline Age (yrs) & $64.03 \pm 11.06$ & $67.81 \pm 8.99$ & $73.24 \pm 5.29$ & 0.002 \\
\hline Gender (M/F) & 3.57 & $72 / 32$ & 6.00 & 0.209 \\
\hline BMI & $23.78 \pm 3.62$ & $27.08 \pm 7.04$ & $28.59 \pm 3.86$ & 0.010 \\
\hline \multicolumn{5}{|l|}{ Smoking habit } \\
\hline Non smokers & $4(12.5)$ & $17(16.3)$ & $4(19.0)$ & \multirow{3}{*}{0.818} \\
\hline Smokers & $16(50.0)$ & $42(40.4)$ & $10(47.6)$ & \\
\hline Ex smokers & $12(37.5)$ & $45(43.3)$ & $7(33.3)$ & \\
\hline FEV1 & $1.46 \pm 0.56$ & $1.23 \pm 0.55$ & $1.07 \pm 0.40$ & 0.028 \\
\hline FVC & $2.76 \pm 0.79$ & $2.30 \pm 0.90$ & $1.93 \pm 0.64$ & 0.002 \\
\hline FVC\% & $75.83 \pm 15.94$ & $69.32 \pm 18.26$ & $59.85 \pm 14.07$ & 0.005 \\
\hline $\mathrm{CRP}$ & $26.68 \pm 30.17$ & $20.52 \pm 25.31$ & $40.38 \pm 40.51$ & 0.266 \\
\hline Leukocyte count & $9.92 \pm 2.81$ & $8.44 \pm 2.38$ & $10.57 \pm 4.76$ & 0.291 \\
\hline
\end{tabular}

$\mathrm{BMI}$ = body mass index; FEV1 = forced expiratory volume in 1 second; FVC = forced vital capacity; FVC $\%$ = percent predicted forced vital capacity; $\mathrm{CRP}=\mathrm{C}$-reactive protein

Table 4. Demographic characteristics of patients in relation to COPD Assessment Test (CAT) values

\begin{tabular}{|c|c|c|c|c|c|}
\hline & & High CAT & Low CAT & & $\mathrm{n}$ \\
\hline & & $\mathrm{n}=79$ & $\mathrm{n}=78$ & & $\mathrm{p}$ \\
\hline Age (yrs) & & $69.15 \pm 8.77$ & $66.36 \pm 9.85$ & 1.876 & 0.063 \\
\hline Gender $(\mathrm{M} / \mathrm{F})$ & & $60 / 19$ & $55 / 23$ & 0.347 & 0.556 \\
\hline Smoking habit & Non smoking & 11 & 14 & & \\
\hline & Smokers & 36 & 32 & & 0.745 \\
\hline & Ex smokers & 32 & 32 & & \\
\hline Exacerbations & Rare & 1 & 41 & 50.123 & 0001 \\
\hline & Frequent & 78 & 37 & & $<0.001$ \\
\hline BMI & & $25.44 \pm 4.79$ & $27.78 \pm 7.32$ & 2.355 & 0.020 \\
\hline CRP & & $37.11 \pm 32.09$ & $5.75 \pm 6.99$ & 4.380 & $<0.001$ \\
\hline Leukocyte count & & $9.97 \pm 3.23$ & $7.66 \pm 2.25$ & 3.149 & 0.002 \\
\hline
\end{tabular}

$\mathrm{BMI}=$ body mass index; $\mathrm{CRP}=\mathrm{C}$-reactive protein

Patients with a high $\mathrm{mMRC}$ score had statistically more frequent exacerbations $(\mathrm{p}<0.001)$. CRP was statistically significantly higher in patients with a high mMRC score $(p<0.001)$. This trend was not observed for leukocyte count according to $\mathrm{mMRC}$ scale. These data are shown in Table 6.

Patients with a high mMRC score had statistically significantly lower values of FEV1 (L), FEV1\%,
$\mathrm{FVC}(\mathrm{L})$ and $\mathrm{FVC} \%(\mathrm{p}<0.001$ all), and lower values of $\mathrm{HCO} 3$ in arterial blood $(\mathrm{p}=0.002)$. The values of pCO2 in arterial blood were statistically significantly higher in patients with a high mMRC score ( $\mathrm{p}=0.019)$.

There was a statistically significant correlation between CAT score and mMRC dyspnea scale $($ rho $=0.963, p<0.001)$ (Fig. 1). 
Table 5. Values of examined parameters compared to COPD Assessment Test (CAT) score

\begin{tabular}{|l|c|c|c|c|}
\hline & High CAT & Low CAT & \multirow{2}{*}{} & \multirow{2}{*}{$\mathrm{p}$} \\
\cline { 2 - 4 } & $\mathrm{n}=79$ & $\mathrm{n}=78$ & & \\
\hline FEV1 & $0.95 \pm 0.29$ & $1.57 \pm 0.57$ & 8.533 & $<0.001$ \\
\hline FEV1\% & $37.59 \pm 10.33$ & $56.70 \pm 12.54$ & 10.409 & $<0.001$ \\
\hline FVC & $1.95 \pm 0.60$ & $2.74 \pm 0.94$ & 6.277 & $<0.001$ \\
\hline FVC $\%$ & $60.02 \pm 15.13$ & $78.87 \pm 15.13$ & 7.806 & $<0.001$ \\
\hline pH & $7.42 \pm 0.06$ & $7.43 \pm$ & 0.872 & 0.386 \\
\hline pO2 & $57.72 \pm 10.72$ & $63.77 \pm 9.03$ & 2.504 & 0.016 \\
\hline pCO2 & $45.63 \pm 13.65$ & $40.14 \pm 5.29$ & 2.527 & 0.014 \\
\hline HCO3 & $28.16 \pm 4.27$ & $26.06 \pm 3.16$ & 2.355 & 0.025 \\
\hline sO2 & $88.02 \pm 8.48$ & $91.54 \pm 4.65$ & 2.319 & 0.023 \\
\hline
\end{tabular}

FEV1 = forced expiratory volume in 1 second; FVC = forced vital capacity; FEV1\% = FEV1/FVC ratio; FVC\% = percent predicted forced vital capacity; $\mathrm{pCO} 2$ = partial carbon dioxide pressure; $\mathrm{HCO} 3$ = bicarbonate; $\mathrm{sO} 2$ = oxygen saturation

\section{Discussion}

Our research showed the CRP value to correlate with the severity of the COPD clinical presentation. These results are in favor of the proven fact that COPD is a systemic inflammatory disease which primarily affects the lungs ${ }^{17-20}$. Similar results were obtained in the studies which suggest that the reduced lung function in COPD is associated with increased levels of systemic inflammatory markers ${ }^{20-24}$. Although leukocyte

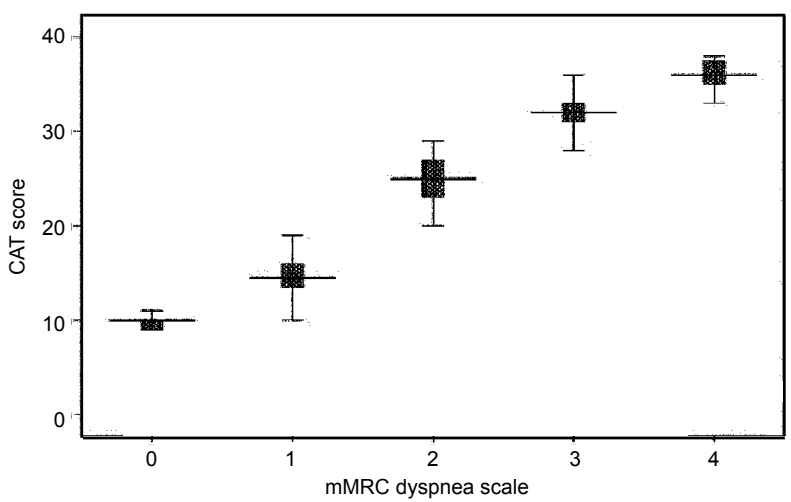

Fig. 1. Correlation between COPD Assessment Test (CAT) score and values of modified Medical Research Council (mMRC) dyspnea scale.

count is considered as a marker of systemic inflammation in $\mathrm{COPD}^{25}$, in our study leukocyte count did not show any significant correlation with the severity of COPD. Several studies showed that leukocyte count was sometimes poor predictor of mortality in COPD patients ${ }^{25}$.

In the present study, no statistically significant correlation was found between the level of CRP and leukocyte count and comorbidities. This result could be of great importance because it might suggest that $\mathrm{CRP}$ and leukocyte count are independent predictors of systemic inflammation and are not related to co-occurring diseases. Inflammatory response at the

Table 6. Demographic characteristics of patients in relation to modified Medical Research Council (mMRC) scale values

\begin{tabular}{|l|l|c|c|c|c|}
\hline & & High $\mathrm{mMRC}$ & Low $\mathrm{mMRC}$ & \multirow{2}{*}{$\mathrm{p}$} \\
\cline { 3 - 5 } & & $\mathrm{n}=108$ & $\mathrm{n}=49$ & & \\
\hline Age (yrs) & & $68.82 \pm 9.25$ & $65.43 \pm 9.38$ & 2.111 & 0.093 \\
\hline Gender (M/F) & & $79 / 29$ & $36 / 13$ & 0.002 & 0.966 \\
\hline Smoking habit & Non smokers & 16 & 9 & & \multirow{2}{*}{0.211} \\
\hline & Smokers & 43 & 25 & & \\
\hline & Ex smokers & 49 & 15 & & \\
\hline Exacerbations & Rare & 4 & 38 & 90.078 & \multirow{2}{*}{$<0.001$} \\
\hline & Frequent & 104 & 11 & & \\
\hline BMI & & $26.26 \pm 6.12$ & $27.36 \pm 6.62$ & 1.203 & 0.229 \\
\hline CRP & & $30.87 \pm 31.51$ & $6.10 \pm 8.05$ & 3.120 & 0.002 \\
\hline Leukocyte count & & $9.41 \pm 3.17$ & $7.96 \pm 2.57$ & 1.756 & 0.079 \\
\hline
\end{tabular}

$\mathrm{BMI}=$ body mass index $\mathrm{CRP}=\mathrm{C}$-reactive protein 
lung level to noxious agents causes systemic inflammatory changes and results in significant extrapulmonary effects that contribute to the increase of CRP and leukocyte count ${ }^{2}$. In support of this interpretation, some research results indicate a higher rate of association of COPD with nutritional abnormalities, skeletal muscle dysfunction and an increased risk of diseases such as cardiovascular, metabolic, neurological and other diseases ${ }^{26,27}$. Lower CAT scores were associated with lower values of CRP and leukocyte count, which supports the previously reported results $^{28}$. Given the fact that lower CAT scores are associated with better spirometry and blood gas analysis results ${ }^{16-18,29}$, lower values of CRP and leukocyte count indicate better clinical profile of COPD, as also shown in our study.

Lower values of the mMRCA dyspnea scale are associated with lower CRP and leukocyte count. The results of our study indicated that this type of relationship could only be applied to CRP level, but not to leukocyte count. These results are consistent with previously reported results ${ }^{30-32}$. Lower values of the mMRC dyspnea scale are associated with better spirometry and blood gas analysis results in COPD. Thus, we can conclude that lower values of CRP correlate better with clinical findings in these patients. Some results of our study indicate that the value of CRP should be analyzed during acute exacerbation of COPD in order to assess the degree of systemic inflammation, as suggested from several other researches ${ }^{17,18,29}$.

We also found significant correlation between CAT and mMRC dyspnea scale. Similar results have been reported from other studies ${ }^{28,33}$.

The mMRC dyspnea scale and CAT provide comprehensive assessment of the overall impact of the disease on the quality of life in COPD patients. In clinical setting, it is useful to use some other parameters to assess the severity of COPD. In addition to lung function, which is an essential component for the diagnosis and defining the severity of COPD, the frequency of exacerbations, comorbidities, blood gas analysis, blood inflammatory markers (CRP and leukocyte count) should also be taken in consideration.

The CRP level in COPD exacerbation may be an independent predictor of the severity and clinical findings in these patients.

\section{References}

1. Celli BR, Macnee W, Agusti A, et al. Standards for diagnosis and treatment of patients with COPD: a summary of the ATS/ERS position paper. Eur Respir J. 2004;23:932-46.

2. Global Initiative for Chronic Obstructive Lung Disease. Global strategy for the diagnosis, management, and prevention of chronic obstructive pulmonary disease. 2013. Available from: http://www.goldcopd.com. Accessed November 20, 2013.

3. Murray CJL, Lopez AD. Alternative projections of mortality and disability by cause 1990-2020. Global burden of disease. Lancet. 1997;349:1498-504. doi: 10.1056/NEJMra1201534.

4. Viegi G, Pisteli F, Sherrill DL, et al. Definition, epidemiology and natural history of COPD. Eur Respir J. 2007;30:9931013.

5. CazzolaM, MacneeW, MartinezFJ, et al. Outcomes of COPD pharmacological trials: from lung functions to biomarkers. Eur Respir J. 2008;31:416-69. doi: 10.1183/09031936.00099306.

6. Meguro M, Barley EA, Spencer S, et al. Development and validation of an improved, COPD-specific version of the St. George Respiratory Questionnaire. Chest. 2007;132:456-63. doi: 10.1136/thx.2010.139121.

7. Jones P, Harding G, Wiklund I, et al. Improving the process and outcome of care in COPD: development of a standardised assessment tool. Prim Care Respir J. 2009;18:20815. doi: 10.4104/pcrj.2009.00053.

8. Jones PW, Harding G, Berry P, et al. Development and first validation of the COPD Assessment Test. Eur Respir J. 2009;34:648-54. doi: 10.1183/09031936.00102509.

9. Miravittles M, Anzueto A, Legnani D, Forstmeier L, Forgel M. Patient's perception of exacerbations of COPD - the PERCEIVE study. Respir Med. 2007;101(3):453-60.

10. Mazur W, Kupiainen H, Pitkaniemi J, et al. Comparison between the disease-specific Airways Questionnaire 20 and the generic 15D instruments in COPD. Health Qual Life Outcomes. 2011;9:4. doi:10.1093/rheumatology/ket265.

11. Braido F, Baiardini I, Menoni S, et al. Disability in COPD and its relationship to clinical and patient-reported outcomes. Curr Med Res Opin. 2011;27(5):981-6. doi:10.2147/COPD. S32675.

12. Fletcher CM. Standardized questionnaire on respiratory symptoms: a statement prepared and approved by the MRC Committee on the Aetiology of Chronic Bronchitis. Br Med J. 1960;2:1665.

13. Gross NJ. Chronic obstructive pulmonary disease outcome measurements: what is important? What's useful? Proc Am Thorac Soc. 2005;2(4):267-71.

14. Miravittles M, Ferrer M, Pont A, et al. Exacerbations impair quality of life in patients with chronic obstructive pulmonary disease: a 2-year follow up study. Thorax. 2004;59(5):387-95. doi: 10.1186/1477-7525-11-147. 
15. Miravittles M. Prevention of exacerbations of COPD with pharmacotherapy. Eur Respir Rev. 2010;19(116):119-26. doi: 10.1007/s11908-012-0255-7.

16. Anzueto A. Impact of exacerbations on COPD. Eur Respir Rev. 2010;19(116): 113-8. doi: 10.1183/09059180.00002610.

17. Pinto-Plata VM, Mullerova H, Toso JF, et al. C-reactive protein in patients with COPD, control smokers and non-smokers. Thorax. 2006;61:23-8. doi: 10.3399/bjgp12X654605.

18. Piehl-Aulin K, Jones I, Lindvall B, et al. Increased serum inflammatory markers in the absence of clinical and skeletal muscle inflammation in patients with chronic obstructive pulmonary disease. Respiration. 2009;78:191-6.

19. Dev D, Wallace E, Sankaran R, Cunniffe J, Govan JRW, Wathen CG, Emmanuel FX. Value of C-reactive protein measurements in exacerbations of chronic obstructive pulmonary disease. Respir Med. 1998;92: 664-7.

20. De Torres JP, Cordoba-Lanus E, Lopez-Aguilar C, Muros De Fuentes M, Montejo De Garsini A, Aguirre-Jaime A, Celli BR, Casanova C. C-reactive protein levels and clinically important predictive outcomes in stable COPD patients. Eur Respir J. 2006;27:902-7.

21. Gan WQ, Man SFP, Senthilselvan A, Sin DD. Association between chronic obstructive pulmonary disease and systemic inflammation: a systemic review and a meta-analysis. Thorax. 2004;59:574-80. doi: 10.1186/1465-9921-11-63.

22. Lee TM, Lin MS, Chang NC. Usefulnes of C-reactive protein and interleukin- 6 as predictors of outcomes in patients with chronic obstructive pulmonary disease receiving provastatin. Am J Cardiol. 2008;101:530-5.

23. Karadag F, Kirdar S, Kurul AB, Ceylan E. The value of C-reactive protein as a marker of systemic inflammation in stable chronic obstructive pulmonary disease. Eur J Internal Med. 2008;19:104-8. doi: 10.1007/978-1-60761-673-3_2.

24. Barnes PJ, Shapiro SD, Pauwels RA. Chronic obstructive pulmonary disease: molecular and cellular mechanisms. Eur Respir J. 2003;22:672-88.
25. Moberg M, Vestbo J, Martinez G, Lange P, Ringbaek T. Prognostic value of $\mathrm{C}$-reactive protein, leukocytes, and vitamin D in severe chronic obstructive pulmonary disease. Sci World J. 2014;2014:1-8. doi: 10.1155/2014/140736.

26. Alvar G, Agusti N. Systemic effects of chronic obstructive pulmonary disease. Proc Am Thorac Soc. 2005;2:367-70.

27. Živković D. Effect of delays on survival in patients with lung carcinoma in Montenegro. Acta Clin Croat. 2014;53:(4):390-8.

28. Mackay AJ, Donaldson GC, Patel AR, Jones PW, Hurst JR, Wedzicha JA. Usefulness of the Chronic Obstructive Pulmonary Disease Assessment Test to evaluate severity of COPD exacerbations. Am J Respir Crit Care Med. 2012;185(11):1218-24. doi: 10.1164/rccm.201110-1843OC .

29. Hurst JJ, Vestbo J, Anzueto A, Locantore N, Müllerova H, Tal-Singer R, et al. Susceptibility to exacerbation in chronic obstructive pulmonary disease. NEng1J Med. 2010;363:112838. doi: 10.1056/NEJMoa0909883.

30. Greenberg SB, Allen MA, Wilson J, Atmar RL. Respiratory viral infections in adults with and without chronic obstructive pulmonary disease. Am J Respir Crit Care Med. 2000;162:167-73. doi: 10.1136/pgmj.2004.019182.

31. Allegra L, Blasti, De Bernardi B, Cosentini R, Tarsia P. Antibiotic treatment and baseline severity of disease in acute exacerbations of chronic bronchitis: a reevaluation of previously published data of placebo controlled randomized study. Pulm Pharmacol Ther. 2001;14:149-55.

32. Saches AP, Koeter GH, Gronier KH, Van Der Waaij D, Schiphuis J, Meyboom-De Jong B. Changes in symptoms, peak expiratory flow, and sputum flora during treatment with antibiotics of exacerbations in patients with chronic obstructive pulmonary disease in general practice. Thorax. 1995;50:75863.

33. Jones PW, Brusselle G, Dal Negro RW, Ferrer M, Kardos $\mathrm{P}$, et al. Properties of the COPD assessment test in a crosssectional European study. Eur Respir J. 2011;38:29-35. doi: 10.3349.ymj.2013.54.5.1214. 
Sažetak

KORELACIJA IZMEĐU C-REAKTIVNOG PROTEINA I STUPNJA TEŽINE KOPB

\section{N. Milačić, B. Milačic, M. Milojković, S. Ljubisavljević, S. Vodopić, M. Hasanbegović i M. Đurovic}

Kronična opstruktivna plućna bolest (KOPB) je progresivna upalna bolest pluća obilježena sistemskom upalom. Cilj ovoga istraživanja bio je utvrditi korelaciju između parametara sistemske upale, tj. C-reaktivnog proteina (CRP) i ukupnog broja leukocita s kliničkim i parakliničkim pokazateljima bolesti. U istraživanje je bilo uključeno 157 bolesnika s KOPB koji su ambulantno i bolnički liječeni na Klinici za plućne bolesti Knez Selo Kliničkog centra Niš u razdoblju od šest mjeseci, i to tijekom faze pogoršanja KOPB. Kod svakog bolesnika simptomi KOPB su se procjenjivali pomoću testa COPD Assessment Test (CAT) i ljestvice mMRC-dispneja. Uz to, procjenjivali su se parametri plućne funkcije (FEV1 i FVC), kao i acidobazni status, indeks tjelesne mase, povijest pogoršanja i komorbiditeti. Razina CRP, ali ne i leukociti, pokazala je značajnu korelaciju s težinom kliničke prezentacije prema klasifikaciji GOLD. Viša razina CRP nađena je kod bolesnika s višom klasom prema klasifikaciji GOLD, odnosno kod bolesnika s težim oblikom bolesti (niži FEV1) u egzacerbaciji $(p<0,001)$. Nije bilo statistički značajne razlike u razini CRP i broju leukocita u odnosu na komorbiditete $(p=0,29)$. Razina CRP je bila viša u bolesnika s visokim zbirom CAT i ljestvicom mMRC-dispneja ( $\mathrm{p}<0,001)$. Korelacijska analiza je pokazala povezanost između razine CRP i ljestvice mMRC-dispneja, ali je ta korelacija izostala između razine leukocita i vrijednosti ljestvice mMRC-dispneja. Zaključuje se kako razina CRP tijekom faze pogoršanja KOPB može biti neovisni prediktor težine bolesti, ali i pokazatelj parakliničkih karakteristika kod ovih bolesnika.

Ključne riječi: Plućna bolest; Kronična opstruktivna plućna bolest - dijagnostika; Kronična opstruktivna plućna bolest - klasifikacija; C-reaktioni protein; Respiratorni funkcionalni testovi; Stupanj težine bolesti, određivanje; Ankete i upitnici 